\title{
Attenuated plant viruses: preventing virus diseases and understanding the molecular mechanism
}

\author{
Masamichi Nishiguchi · Kappei Kobayashi
}

Received: 24 December 2010/Accepted: 7 May 2011/Published online: 9 June 2011

(C) The Phytopathological Society of Japan and Springer 2011

\begin{abstract}
Attenuated viruses have been isolated and studied not only as a practical means of controlling virus diseases but also to gain a molecular understanding of viral virulence and cross protection. They have been isolated from crop fields and generated through high/low temperature treatment or by mutagens such as nitrous acid and ultraviolet irradiation. Some viruses have been beneficially used in fields and evaluated for one or more decades. Molecular genetic studies on attenuated viruses have revealed that amino acid substitutions are located in replicase and the movement protein in tobamovirus, protein $2 \mathrm{~b}$ for cucumovirus, and P1 and HC-Pro for potyvirus. In most cases, with a few exceptions, symptom attenuation is positively correlated with a reduced level of RNA silencing suppression. Molecular mechanisms underlying virus attenuation and cross protection and the rationale for practical use of attenuated viruses for effective virus disease control are discussed.
\end{abstract}

Keywords Attenuated virus - Virulence ·

Cross protection - Interference - RNA silencing ·

Posttranscriptional gene silencing (PTGS) .

Viral silencing suppressor

\section{Introduction}

Attenuated or mild virus strains have been used to protect crops against severe strains of the same or related virus species. This method of crop protection is based on the

M. Nishiguchi $(\varangle) \cdot$ K. Kobayashi

246-Ehime University, 3-5-7 Tarumi,

Matsuyama 790-8566, Japan

e-mail: mnishigu@agr.ehime-u.ac.jp phenomenon called cross protection/interference, which was first reported by McKinney (1929), who showed that tobacco plants infected with a yellow strain of Tobacco mosaic virus (TMV) show resistance to a severe mosaic strain of TMV. Salaman (1933) reported that tobacco inoculated with a mild strain of Potato virus $X(\mathrm{PVX})$ is resistant to severe strains of PVX. Holmes (1934) isolated a masked strain (M) of TMV from tomato stems that had been incubated at $34.5^{\circ} \mathrm{C}$ for 14 days after inoculation with a severe strain and elicited some resistance in tobacco and tomato against a severe strain. Since then, there have been a number of reports on vegetables and fruit trees including tomato, cucumber, cacao, papaya, and citrus (reviewed by Gal-On and Shiboleth 2006).

More recently, transgenic plants with a viral sequence have been proven to confer resistance to the virus from which the transgene was derived or to related viruses (Prins et al. 2008). One remarkable example is transgenic papaya; with the coat protein (CP) gene of Papaya ringspot virus (PRSV), it expresses extreme resistance to PRSV (Fuchs and Gonsalves 2008), although the resistance mechanism in this papaya appears to be CP-mediated. These papaya fruits have been sold in US and Canadian markets.

The mechanism of resistance in these transgenic plants has been interpreted by either of two distinct models: protein-mediated or RNA-mediated mechanisms (Baulcombe 1996). In the former model, pre-existing CP affects the virus infection process, i.e., inhibition of uncoating and replication as shown for TMV (Bendahmane et al. 2007). In the latter, the resistance results from RNA silencing by host plants (Ratcliff et al. 1999).

The phenomenon of RNA silencing has been thought to play a pivotal role in defending eukaryotes against invasive genes such as viruses, transposons and transgenes (Ding and Voinnet 2007). To counteract this host defense 
mechanism, viruses have evolved a means of counterattacking host plants: virus encoded suppressor(s) of RNA silencing (Béclin et al. 1998; Brigneti et al. 1998; Kasschau and Carrington 1998). It is generally accepted that viral RNA silencing suppressors (VRSs) are more or less related to viral pathogenicity because the VRS represses silencing, that is, virus infection in host plants is more vigorous, which may virtually result in more severe symptoms (DíazPendón and Ding 2008).

In this review, the present status of attenuated virus studies is described first in relation to a means of protecting crops from viral diseases. Then the mechanism of viral attenuation and cross protection is discussed with reference to RNA silencing. Finally, some characteristics of attenuated viruses that are needed for effective virus disease control are discussed in light of the molecular understanding of attenuated viruses.

\section{Selection, isolation and induction of attenuated viruses}

The most commonly used attenuated virus strains have been isolated from naturally occurring variants that cause attenuated symptoms or by random or direct mutagenesis of wild, severe strains using nitrous acid or ultraviolet irradiation. Nitrous acid is a well-known mutagen that deaminates cytosine and adenine to produce uracil and hypoxanthine, respectively, and thus, induces transitional mutations. UV irradiation causes the formation of pyrimidine dimers in DNA as well as in RNA (Brégeon and Sarasin 2005) and likely induces any type of mutation, including base changes and insertion/deletions.

Some attenuated viruses have been isolated after cultivation at higher $\left(35^{\circ} \mathrm{C}\right)$ or lower $\left(15^{\circ} \mathrm{C}\right)$ temperatures than the optimal. The underlying mechanism of attenuated virus generation after temperature treatment is not yet clear. However, the concept of quasispecies supports that temperature treatment would facilitate the selection of mutated viruses from preexisting variation rather than that the treatment induces the mutation of a virus genome. A pseudorecombinant RNA virus is one choice for selecting an attenuated virus by the exchange of a viral RNA segment with the corresponding RNA from an attenuated strain in multisegmented viruses including Cucumber mosaic virus (CMV). Some attenuated viruses (strains/ isolates) are listed in Table 1.

An attenuated strain of Tomato mosaic virus (ToMV), $\mathrm{L}_{11} \mathrm{~A}$, has been in practical use for over 30 years to protect tomato in greenhouses against severe strain infection (Oshima 1981). Tomato cultivars carrying resistance genes (Tm-1, Tm-2 and/or $T m-2^{a}$ ) have been developed, and the frequency of pre-inoculation with the attenuated strain has decreased. However, when a resistant variety is not available, an attenuated strain is still required. In Europe and New Zealand, an attenuated strain of ToMV (MII-16), isolated by treatment with nitrous acid, was once used

Table 1 Examples of attenuated viruses used for cross protection

\begin{tabular}{|c|c|c|c|}
\hline Virus & Strain or isolate (method) (country) & Crop & \\
\hline CGMMV & SH33b ${ }^{\text {b,d,e }}$ (Japan) & Muskmelon & Motoyoshi and Nishiguchi (1988) \\
\hline $\mathrm{CMV}$ & $\mathrm{S} 1^{\mathrm{a}, \mathrm{f}}, \mathrm{S} 52^{\mathrm{a}, \mathrm{f}}$ (China); KO3 ${ }^{\mathrm{a}, \mathrm{f}}, \mathrm{CM} 5^{\mathrm{a}}$ (Japan) & Tomato, Tobacco, etc. & $\begin{array}{l}\text { Kosaka and Fukunishi (1997), Sayama et al. (1993), } \\
\text { Tien and Wu (1991) }\end{array}$ \\
\hline CSSMV & Mild strains ${ }^{\mathrm{a}}$ (Ghana) & Cacao & Hughes and Ollennu (1994) \\
\hline $\mathrm{CTV}$ & HM55 $^{\mathrm{a}}, \mathrm{M}-16 \mathrm{~A}^{\mathrm{b}}$ (Japan), mild strains ${ }^{\mathrm{a}}$ (Brazil) & Citrus & Costa and Müller (1980), Ieki et al. (1997), Sasaki (1974) \\
\hline PMMoV & $\mathrm{Pa} 18^{\mathrm{b}}, \mathrm{C}-1421^{\mathrm{b}}$ (Japan) & Pepper & Goto et al. (1984), Nagai (1987) \\
\hline PRSV & HA5-1 ${ }^{\mathrm{d}}$ (USA, Taiwan) & Papaya & Yeh and Gonsalves (1984) \\
\hline SMV & Ala15-M2 ${ }^{\mathrm{c}}$ (Japan) & Soybean & Kosaka and Fukunishi (1993) \\
\hline TMV & $\mathrm{M}^{\mathrm{b}}$ (USA) & Tobacco & Holmes (1934) \\
\hline ToMV & $\begin{array}{l}\mathrm{L}_{11} \mathrm{~A}^{\mathrm{b}} \text { (Japan), MII- } 16^{\mathrm{d}} \\
\quad \text { (Holland, UK, etc.), } \mathrm{K}^{\mathrm{d}} \text { (China) }\end{array}$ & Tomato & Goto and Nemoto (1971), Rast (1975), Yang et al. (2002) \\
\hline ZYMV & ZY95 $5^{\mathrm{c}, \mathrm{d}}$ (Japan) & Cucumber & Kosaka and Fukunishi (1997) \\
\hline
\end{tabular}

CGMMV, Cucumber green mottle mosaic virus; CMV, Cucumber mosaic virus; CSSMV, Cocoa swollen shoot mosaic virus; CTV, Citrus tristeza virus; PMMoV, Pepper mild mottle virus; PRSV, Papaya ringspot virus; SMV, Soybean mosaic virus; TMV, Tobacco mosaic virus; ToMV, Tomato mosaic virus; ZYMV, Zucchini yellow mosaic virus

a Natural selection

b High temperature

c Low temperature

${ }^{d}$ Nitrous acid

e Ultraviolet irradiation

${ }^{\mathrm{f}}$ Satellite RNA 
(Rast 1975). By the same method, an attenuated strain (ToMV-K) was produced and has been used in China for two decades (Yang et al. 2002). An attenuated strain (SH33b) of Cucumber green mottle mosaic virus (CGMMV) was isolated through nitrous acid and UV irradiation and has been used for muskmelon in greenhouses in Japan (Motoyoshi and Nishiguchi 1988). Some attenuated strains (Pa18 and C-1421) of Pepper mild mottle virus (PMMoV) have been used in pepper fields (Goto et al. 1984; Nagai 1987).

Tomato and tobacco diseases by CMV are also controlled by attenuated strains in Japan and China (Sayama et al. 1993; Tien and Wu 1991). In some cases, satellite RNA was added to field isolates of CMV to attenuate symptoms (Sayama et al. 1993). In Japan, this strategy has been applied not only to tomato but also to cucumber, petunia and Texas bluebell (Eustoma grandiflorum) (Sayama 1996).

Soybean has been preventively inoculated with an attenuated strain (Ala-15) of Soybean mosaic virus, which was isolated from soybean plants incubated at a lower temperature $\left(15^{\circ} \mathrm{C}\right)$ (Kosaka and Fukunishi 1993). An attenuated strain (ZYMV-2002) of Zucchini yellow mosaic virus (ZYMV) isolated through low temperature treatment has also been applied to cucumber (Kosaka et al. 2006). Papaya in Hawaii and Taiwan was tested for cross protection by an attenuated strain of PRSV (HA-21), showing significant protection (Yeh et al. 1988). Some attenuated, field-selected strains of Cacao swollen shoot virus (CSSV) have been used for cross protection on cacao to prevent severe damage from CSSV (Hughes and Ollennu 1994).

\section{Side effects of preventive inoculation with attenuated virus and monitoring attenuated viruses applied to fields}

The goal of preventive inoculation with an attenuated virus is to protect crops from infection with severe strains. The quantity and/or quality of the final harvested products are significantly important, and they should have a similar level of quality to virus-free control. In the case of CMV, the content of vitamin $\mathrm{C}$ was higher in tomato inoculated with attenuated CMV compared with that in virus-free tomato (Sayama 1996). This result is an unexpected advantage of using an attenuated virus.

In monitoring attenuated CMV in fields, necrotic spot, a serious disease that manifests itself on the surface of the fruits, was markedly reduced by application of the attenuated CMV. The longer the attenuated virus was used, the less frequent was disease occurrence, and there was no serious damage for 10 years (Sayama et al. 2001). When an attenuated strain of CGMMV was monitored in greenhouses after serial use of the attenuated strain, no substantial disease damage was found, implying that preventive inoculation reduces the chance of infection by a severe strain and that the attenuated strain is inactivated more effectively than the wild severe strain $\mathrm{SH}$ (Anonymous 1988).

\section{Molecular and biological characterization of attenuated viruses}

\section{Tobamovirus}

Attenuated virus genomes have been reported for several tobamoviruses (Table 1; Fig. 1a). In $\mathrm{L}_{11} \mathrm{~A}, 11$ base substitutions were located in the genome when compared with the wild-type, severe strain L (Nishiguchi et al. 1985). Of those, only three at amino acid (aa) positions 348, 760 and 896 in the 130-kDa protein caused amino acid replacements. These three amino acid replacements were compared with those in $\mathrm{L}_{11}$, from which $\mathrm{L}_{11} \mathrm{~A}$ was derived (Goto and Nemoto 1971). Only one of them, the change from cysteine (C) in wild-type strains to tyrosine $(\mathrm{Y})$ in attenuated strains at aa position 348 (at nucleotide position 1117), was conserved within these two attenuated virus strains $\left(\mathrm{L}_{11} \mathrm{~A}\right.$ and $\left.\mathrm{L}_{11}\right)$, suggesting that the amino acid replacement at aa position 348 is important for virus attenuation (Nishiguchi et al. 1985). Kubota et al. (2003) later proved that the change of $\mathrm{C}-\mathrm{Y}$ at aa position 348 in the infectious $\mathrm{L}$ cDNA clone rendered the mosaic symptom into an attenuated phenotype. That mutated clone is referred to as TLJ. It was also found to be the only nucleotide substitution between $\mathrm{L}_{11}$ and $\mathrm{L}$ over the genome (Kubota et al. 2003). They also showed that the wild-type $130-\mathrm{kDa}$ protein had greater RNA silencing suppressor activity than that of the attenuated mutant TLJ, suggesting that the amino acid replacement from $\mathrm{C}$ to $\mathrm{Y}$ at aa position 348 in the $130-\mathrm{kDa}$ protein plays an important role in reducing the RNA silencing suppression activity of the 130-kDa protein. More recently, Hagiwara-Komoda et al. (2008) reported that the 130-kDa protein of ToMV was detected in both a soluble and a crude membrane fraction. The latter contains the TOM1 protein, which is required for multiplication of tobamoviruses in Arabidopsis and tobacco (Asano et al. 2005; Yamanaka et al. 2000). In the NtTOMI (tobacco ortholog of TOM1)overexpressing transgenic tobacco plants, the level of the $130-\mathrm{kDa}$ protein in the soluble fraction was reduced because the overexpressed NtTOM1 recruited and anchored the $130-\mathrm{kDa}$ protein to membranes. The reduced level of the soluble 130-kDa protein resulted in a reduction of RNA silencing suppression. The propagation of both $\mathrm{L}$ and $\mathrm{L}_{11}$ were inhibited in this NtTOM1-overexpressing line, implying that silencing suppression was apparently caused 


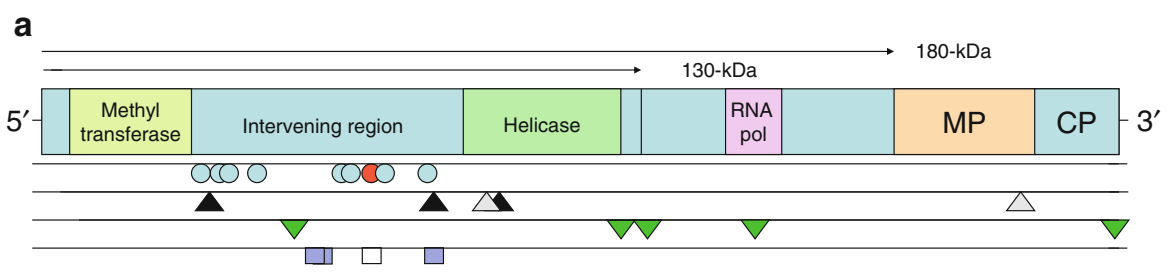

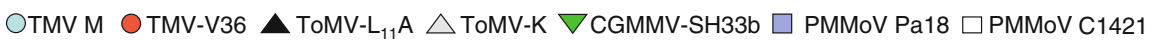

b

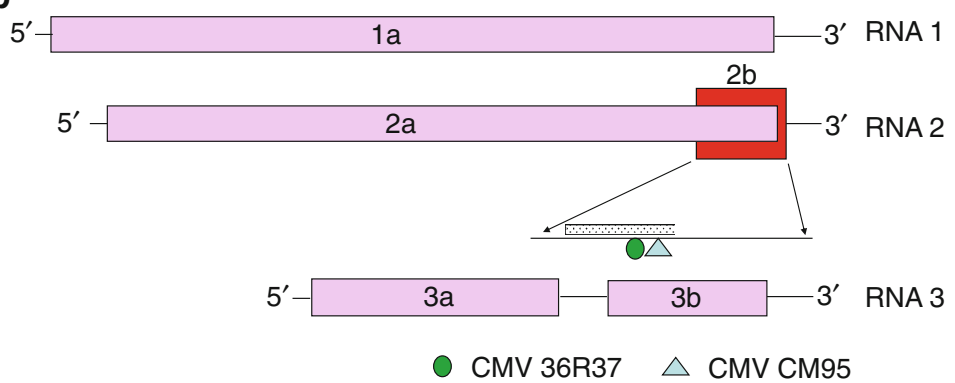

c

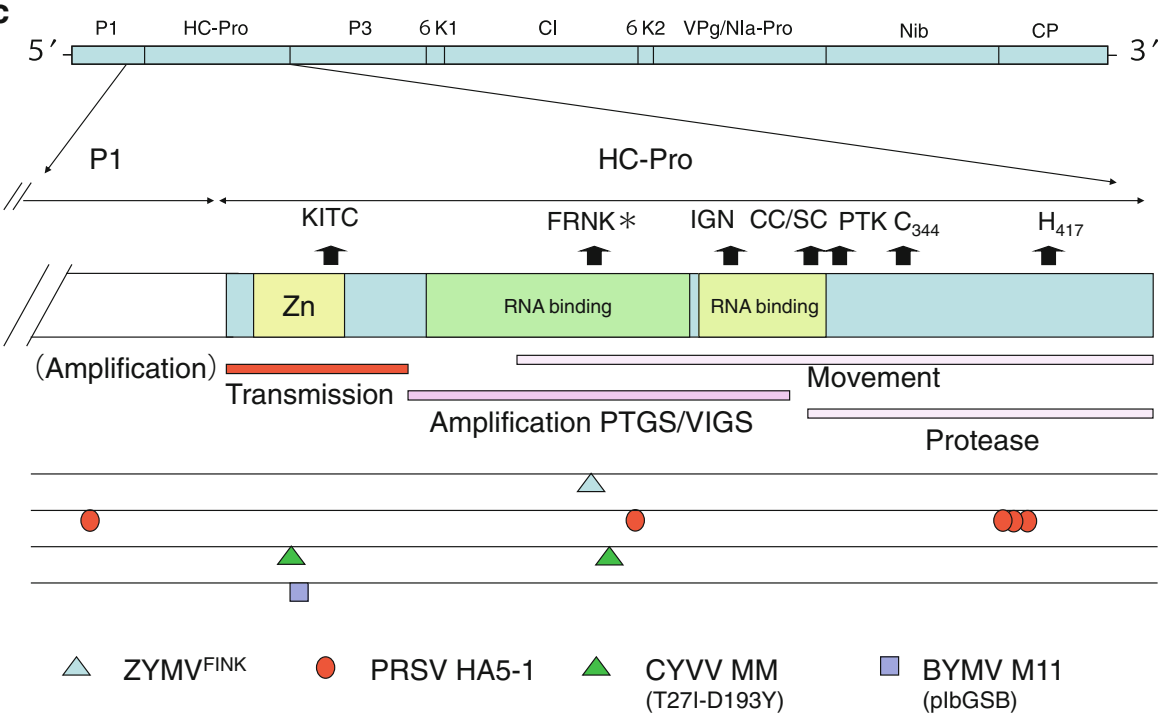

Fig. 1 Location of amino acid substitutions among severe and attenuated strains in tobamovirus, cucumovirus and potyvirus. a Tobamovirus; b cucumovirus; c potyvirus (modified from Plisson et al. 2003). Only amino acid substitutions are described on the genome RNA. Three domains, methyltransferase, helicase and RNA polymerase (RNA pol) are shown in the 180-kDa ORF (Koonin 1991; Shintaku et al. 1996). MP and CP in a represent movement and coat proteins, respectively. Dotted square in b represents arginine-rich region in $2 \mathrm{~b}$ protein (Goto et al. 2007). KITC, FRNK, IGN, CC/SC, C344 and $\mathrm{H} 417$ in c represent domains (single letter of amino acid and number of amino acids from N-terminal of HC-Pro) in HC-Pro (Plisson et al. 2003). Asterisk shows CDNQLD domain, 12 amino acids downstream from FRNK (Desbiez et al. 2010). PTGS

by the $130-\mathrm{kDa}$ protein in the soluble fraction (HagiwaraKomoda et al. 2008). The molecular mechanism underlying the silencing suppression by the tobamovirus $130-\mathrm{kDa}$ protein (replicase protein) (including the $122-\mathrm{kDa}$ protein of cr-TMV and the 126-kDa protein of TMV) is postulated posttranscriptional gene silencing, VIGS virus-induced gene silencing. Tobacco mosaic virus (TMV) M (Shintaku et al. 1996), TMV V-36 (Lewandowski and Dawson 1993), Tomato mosaic virus (ToMV$\mathrm{L}_{11} \mathrm{~A}$ ) (Nishiguchi et al. 1985), ToMV-K (Yang et al. 2002), Cucumber green mottle mosaic virus (CGMMV)-SH33b (Tan et al. 1997), Pepper mild mottle virus (PMMoV)-Pa18 (Ichiki et al. 2005), PMMoV-C1421 (Hagiwara et al. 2002), Cucumber mosaic virus (CMV) 36R37 (Kobori et al. 2005), CMV CM95 (Goto et al. 2007), Zucchini yellow mosaic virus (ZYMV) ${ }^{\mathrm{FINK}}$ (Shiboleth et al. 2007), Papaya ringspot virus (PRSV) HA 5-1 (Chiang et al. 2007), Clover yellow vein virus (ClYVV) MM(T27I-D193Y) (Yambao et al. 2008), Bean yellow mosaic virus (BYMV) M11(pIbGSB) (NakazonoNagaoka et al. 2009)

to prevent formation of the RNA-induced silencing complex (RISC) after siRNA and miRNA syntheses (Csorba et al. 2007; Ding et al. 2004; Kubota et al. 2003; Vogler et al. 2007). The 130-kDa protein was found to bind to double-stranded RNA (dsRNA) but not to single-stranded 
RNA (ssRNA) (Hagiwara-Komoda et al. 2008). The dsRNA-binding activity and RNA-dependent RNA polymerase activity of the $130-\mathrm{kDa}$ protein in the membrane fractions were not significantly different between $\mathrm{L}$ and TLJ. However, the $130-\mathrm{kDa}$ protein level in the soluble fraction was reduced in the attenuated strain TLJ compared with that in the wild-type L, implying that the binding affinity of the attenuated $130-\mathrm{kDa}$ protein to TOM1 or a TOM1-containing membrane is higher than that of the wildtype $130 \mathrm{kDa}$. Yamanaka et al. (2000) showed that the helicase domain of the $130 \mathrm{kDa}$ interacts with TOM1. The mutation at aa position 348 of $130 \mathrm{kDa}$ would alter the structure of the helicase domain, increase the TOM1binding activity, and thus reduce the silencing suppressor activity. Replication protein $(122 \mathrm{kDa})$ of TMV-Cg was found to disturb miRNA biogenesis by binding to small RNA duplexes and changing the miRNA profiles (Kurihara et al. 2007). It would be worth analyzing the difference in the effects of the wild-type and attenuated 130-kDa replication proteins on the miRNA profiles.

Genomic characterization of an attenuated strain (ToMV-K) (Yang et al. 2002) showed that two mutations resulted in the production of UGA ochre and UAA opal nonsense codons in the $126-\mathrm{kDa}$ replicase and MP genes, respectively, and that both mutations were shown to have roles in symptom attenuation by producing the truncated forms of the $126 \mathrm{kDa}$ and MP. The attenuated phenotype of a masked strain (M) of TMV (Table 1) has been characterized in detail (Ding et al. 2004; Shintaku et al. 1996). The TMV-M 126-kDa protein is reported to have a reduced level of suppression of RNA silencing, while that of wildtype TMV-U1 has higher suppressive activity. TMV-M has eight amino acid substitutions in the $128-\mathrm{kDa}$ protein. Each substitution more or less affects symptom attenuation (Ding et al. 2004).

An attenuated strain (SH33b) of CGMMV accumulated approximately two-thirds of the parental strain $\mathrm{SH}$ in melon plants. When the genome sequence of $\mathrm{SH} 33 \mathrm{~b}$ was compared with that of the parental SH, 14 nucleotide substitutions were found, plus three amino acid replacements in the 129-kDa replicase and one in the CP (Tan et al. 1997). Recently, the amino acid at position 479 (E-G) has been suggested to play a role in RNA silencing suppression activity (Chen et al. 2007).

The genomes of attenuated strains (Pa18 and C-1421) of PMMoV were also compared with a severe strain, PMMoV-J. As a result, valine (V) to alanine at a position 649 in C-1421 and lysine to arginine (R) at aa position 549, $\mathrm{V}$ to threonine at aa position 556 and serine to leucine in Pa18 at aa position 760 were responsible for the attenuated phenotype (Hagiwara et al. 2002; Ichiki et al. 2005). Viral amplification of these mutants was $25 \%$ that of PMMoV-J. An artificial mutant that carried these four amino acid changes accumulated at a reduced level in infected plants in comparison to PMMoV-J. The attenuated strain of PMMoV engineered to contain the ToMV $\mathrm{L}_{11}$ A type amino acid mutation $\mathrm{Y}$ or $\mathrm{D}$ at aa 348 or 760 in the corresponding position of the PMMoV 130-kDa protein was reported to induce attenuated symptoms (Tsuda et al. 2007), suggesting a common mechanism underlying symptom attenuation among tobamoviruses. However, symptoms were attenuated after infection with ToMV $\mathrm{L}$ that had a partial deletion in the $3^{\prime}$ noncoding region, but not in PMMoV with the similar deletion (Tsuda et al. 2007). These results indicate that mutations in the tobamovirus genome could have distinct effects on gene function, even if their genomes are highly conserved within the tobamoviruses.

\section{Cucumovirus}

CMV with a defective $2 \mathrm{~b}$ protein caused mild symptoms (Ding et al. 1995). CMV 2b inhibits AGO1-mediated cleavage, implying that $2 \mathrm{~b}$ is involved in biogenesis of the host's small RNA and affects symptom expression (Cillo et al. 2009; Lewsey et al. 2009; Zhang et al. 2006). A severe strain (CM95R) of CMV is a spontaneous mutant from an attenuated strain (CM95), which was selected through a series of local lesion isolations (Kosaka and Fukunishi 1997). The $2 b$ protein encoded by CM95 differs in one amino acid residue from that of CM95R (Goto et al. 2007) (Fig. 1b). The $2 \mathrm{~b}$ protein is known to be involved in virus movement, virulence and posttranscriptional gene silencing (PTGS) suppressor (Brigneti et al. 1998; Shi et al. 2002; Soards et al. 2002). The 2b protein of CM95 showed weak PTGS suppressor activity compared with that of CM95R (unpublished results by Kobori and others in Goto et al. 2007) because of loss of the siRNA-binding property of $2 b$ of CM95. The point mutation in the $2 b$ of CR95 is responsible for binding to siRNA (Goto et al. 2007). Another attenuated strain of CMV, 36R37, also had a different amino acid substitution in 2b (Kobori et al. 2005) (Fig. 1b). Other types of attenuated CMV strains harbor satellite RNA that affects viral pathogenesis. An attenuating satellite RNA has base substitutions and insertions in the region responsible for the necrotic response and an insertion/deletion in other regions (Sayama et al. 1993). The role of these base changes in attenuating symptoms remains to be resolved.

\section{Potyvirus}

As listed in Table 1 and Fig. 1c, there are also reports of attenuated potyviruses (Chiang et al. 2007; Lin et al. 2007b; Yambao et al. 2008). When an attenuated strain (HA5-1) of PRSV was compared with its parent strain HA using an infectious cDNA clone, two amino acid substitutions among three in the $\mathrm{C}$-terminal region of $\mathrm{P} 1$ at aa positions 
309 and 481, and two of four in HC-Pro at aa positions 753 and 944 of HA5-1 appear to be critical in symptom attenuation in papaya (Chiang et al. 2007). In a comparison of attenuated and severe strains of Clover yellow vein virus (ClYVV), two amino acid substitutions in HC-Pro were found to be responsible for symptom attenuation (Yambao et al. 2008). Both mutations caused weaker RNA silencing suppression than the wild type did, suggesting a correlation between viral virulence and silencing suppression activity. In $\mathrm{ZYMV}$, one amino acid substitution from $\mathrm{R}$ to isoleucine $\left(\mathrm{ZYMV}^{\mathrm{FINK}}\right.$ )was found in HC-Pro at aa position 180 in the FRNK motif of the attenuated strain AGII (Shiboleth et al. 2007). Other amino acid substitutions, phenylalanine to leucine and glutamic acid to asparagine at aa positions 205 and 396, respectively, also affected symptom expression in ZYMV (Lin et al. 2007b). A CDNQLD motif, located 12 amino acids downstream from the FRNK, also plays a role in symptom severity (Desbiez et al. 2010). The attenuated strain (GAC mutant) with two amino acid substitutions at aa positions 180 and 396 did not affect RNA silencing suppression, implying that symptom attenuation does not always correlate with reduced RNA silencing suppression (Lin et al. 2007b). Although this strain conferred complete protection, the authors did not mention why. Because the viral accumulation kinetics for the attenuated strain $A G$ were similar to those for the severe strain (Gal-On 2000). This similarity might be responsible for the cross protection ability. In studies with HC-Pro mutants of Tobacco etch virus, hyposuppression of RNA silencing was correlated with milder virulence, but hypersuppression did not correlate with stronger virulence than with the wild type (TorresBarcelo et al. 2008). HC-Pro is known as a multifunctional protein: aphid transmissibility, viral cell-to-cell and longdistance movement, viral amplification, symptom expression, synergism with other viruses, interaction with $20 \mathrm{~S}$ proteasome and cysteine type proteolysis, siRNA binding and silencing suppressor including miR-guided cleavage of target mRNAs (Maia et al. 1996; Plisson et al. 2003; Shiboleth et al. 2007). It is important to determine the structural requirements for RNA silencing suppressor activity, virus attenuation and cross protection.

\section{Mechanisms of cross protection/interference}

There are at least two mechanisms of cross protection: protein mediated and nonprotein mediated (Baulcombe 1996). In the former, the CP of a protecting virus present in cells may inhibit the uncoating step of an incoming virus. This case was first reported by Sherwood and Fulton (1982) who showed difficulty of infection by TMV in the yellow region of leaves with mosaic symptoms. Abel et al. (1986) showed delayed expression of symptoms after inoculation with TMV in CP-expressing transgenic tobacco. When this transgenic tobacco line was inoculated with TMV-RNA, no resistance was detected, indicating the involvement of $\mathrm{CP}$ in the uncoating step. There is a strong correlation between CP accumulation and resistance (Abel et al. 1986; LoeschFries et al. 1987) although the CP-mediated resistance (CPMR) mechanism is not yet fully understood. More recently, Bendahmane et al. (2007) suggested that there are at least two mechanisms for CPMR against TMV: interference by $\mathrm{CP}$ in the disassembly of an infecting virus and interference in the accumulation of viral replication complexes by $\mathrm{CP}$. They stress that the stability of $\mathrm{CP}-\mathrm{CP}$ interaction and the configuration of the quaternary structure would be important for conferring resistance.

Because a viroid, which has neither protein-coding capacity nor proteins (such as CP) that associate with the genome, can also confer cross protection/interference, there must be another mechanism or mechanisms than that mediated by the CP. One such mechanism is gene silencing by the host plant (Ratcliff et al. 1999). In addition to the dsRNA produced during the replication of RNA viruses, highly structured ssRNA is likely to trigger RNA silencing. A recent report, however, implied that theoretical highly structured RNA is not always a good substrate for small RNA synthesis (Qi et al. 2009). When plants are infected with a virus, RNA silencing will be induced in the host plants, and an incoming second virus, which is similar to the first virus, will be targeted for RNA degradation. However, such is not the case in PVX CPMR: the inhibition of RNA silencing did not affect resistance (Bazzini et al. 2006). Recently, Ziebell and Carr (2009) showed cross protection between CMV strains in RNA-silencingimpaired Arabidopsis mutants ( $d c l 2,3$ and 4), suggesting that DCL2, 3 and 4 are not required for cross protection in this system. We cannot exclude the possibility, however, of the involvement of other gene/copy in this system.

Ziebell and Carr (2009) also found that the two CMV strains were mutually exclusive in the same infected region. Although the same phenomena have also been reported in Potyvirus and Cheravirus, the mechanism has not yet been elucidated (Dietrich and Maiss 2003; Takahashi et al. 2007). When these results are considered together, cross protection/interference is not likely due to a single mechanism but to multiple ones (Lin et al. 2007a). Which mechanism plays a major role in the protection would depend upon the particular system and conditions.

\section{From molecular understanding to practical evaluation of attenuated-virus-based control}

Although several attenuated viruses have been used in disease control in commercial fields, their practical use is 
still under debate. For example, Hull (2002) points out that the use of a mild strain for protection is not recommended as a general practice because of (1) some levels of yield reduction, (2) risk as a virus reservoir for other crops, (3) acquisition of virulence by mutation, (4) serious damage from mixed infection with other viruses, (5) labor intensiveness and (6) risk of generating a new pathogenic virus by recombination with other viruses. Although these concerns are based on up-to-date knowledge from molecular biological studies, they are not always true for all virus systems. We emphasize that cross protection is still a practical means of choice for plant virus disease control, although it is recommended only under limited circumstances when no other protective means are available.

Nonetheless, the opposing view helps guide the development of new attenuated viruses having better practical properties. Addressing the issues raised by Hull (2002), we propose the following properties as criteria for a good attenuated virus strain for future development: (1) no symptoms or very mild symptoms are induced in any of the cultivated hosts, and the quality and quantity of the crop products are not reduced, (2) most host tissues are fully infected systemically, (3) they are highly stable genetically without mutating into a severe phenotype, (4) there is no vector transmission to other crops, (5) they protect against a wide range of viruses and strains, (6) the quality/quantity control of the inoculum and inoculations are easy and inexpensive. Of these criteria, genetic stability would be the most important factor for the practical use of attenuated viruses. Schneider and Roossinck (2001) reported that the diversity of RNA virus quasispecies depends on the host species where the viruses replicated. Therefore, the genetic stability of attenuated viruses should be examined in each of the hosts to which they will be applied. Because cross protection does not rely on harmful materials or chemicals such as pesticides and fungicides, it is suitable for sustainable agriculture, which is in high demand. Further molecular study and understanding of cross protection/ interference should pave the way for broadening the practical applications of attenuated viruses.

Acknowledgments We wish to thank Dr. D. Murphy for his English correction. We are very grateful to Drs. K. Sayama, Y. Kosaka, T.U. Ichiki, C. Masuta and T. Yoneyama for their useful information and to Dr. M. Ishikawa for critical reading of part of the manuscript. This work was partially supported by the Ministry of Education, Culture, Sports, Science and Technology of Japan (MEXT), Grant-in-Aid for Scientific Research, 00465001, 2010 to M.N. and 21380032, 2010 to K.K.

\section{References}

Abel PP, Nelson RS, De B, Hoffmann N, Rogers SG, Fraley RT, Beachy RN (1986) Delay of disease development in transgenic plants that express the tobacco mosaic virus coat protein gene. Science 232:738-743

Anonymous (1988) Control of melon mosaic disease by attenuated virus. Shizuoka Prefect Agric Fish Dep Rep. No. 1765, Shizuoka Pref. Gov. Shizuoka, pp 1-12

Asano M, Satoh R, Mochizuki A, Tsuda S, Yamanaka T, Nishiguchi M, Hirai K, Meshi T, Naito S, Ishikawa M (2005) Tobamovirusresistant tobacco generated by RNA interference directed against host genes. FEBS Lett 579:4479-4484

Baulcombe DC (1996) Mechanisms of pathogen-derived resistance to viruses in transgenic plants. Plant Cell 8:1833-1844

Bazzini AA, Hopp HE, Beachy RN, Asurmendi S (2006) Posttranscriptional gene silencing does not play a significant role in Potato virus $X$ coat protein-mediated resistance. Phytopathology 96:1175-1178

Béclin C, Berthomé R, Palauqui J-C, Tepfer M, Vaucheret H (1998) Infection of tobacco or Arabidopsis plants by CMV counteracts systemic post-transcriptional silencing of nonviral (trans)genes. Virology 252:313-317

Bendahmane M, Chen I, Asurmendi S, Bazzini AA, Szecsi J, Beachy RN (2007) Coat protein-mediated resistance to TMV infection of Nicotiana tabacum involves multiple modes of interference by coat protein. Virology 366:107-116

Brégeon D, Sarasin A (2005) Hypothetical role of RNA damage avoidance in preventing human disease. Mutat Res/Fundam Mol Mech Mutagen 577:293-302

Brigneti G, Voinnet O, Li W-X, Ji L-H, Ding S-W, Baulcombe DC (1998) Viral pathogenicity determinants are suppressors of transgene silencing in Nicotiana benthamiana. EMBO $\mathrm{J}$ 17:6739-6746

Chen H, Yamaoka N, Nishiguchi M (2007) Suppression of RNA silencing by $129 \mathrm{~K}$ protein of Cucumber green mottle mosaic virus: comparison between severe and attenuated strains (abstract in Japanese). Jpn J Phytopathol 73:237

Chiang C-H, Lee C-Y, Wang C-H, Jan F-J, Lin S-S, Chen T-C, Raja JAJ, Yeh S-D (2007) Genetic analysis of an attenuated Papaya ringspot virus strain applied for cross-protection. Eur J Plant Pathol 118:333-348

Cillo F, Mascia T, Pasciuto MM, Gallitelli D (2009) Differential effects of mild and severe Cucumber mosaic virus strains in the perturbation of microRNA-regulated gene expression in tomato map to the $3^{\prime}$ sequence of RNA 2. Mol Plant Microbe Interact 22:1239-1249

Costa AS, Müller GW (1980) Tristeza control by cross protection: a US-Brazil cooperative success. Plant Dis 64:538-541

Csorba T, Bovi A, Dalmay T, Burgyán J (2007) The p122 subunit of Tobacco mosaic virus replicase is a potent silencing suppressor and compromises both small interfering RNA- and microRNAmediated pathways. J Virol 81:11768-11780

Desbiez C, Girard M, Lecoq H (2010) A novel natural mutation in HC-Pro responsible for mild symptomatology of Zucchini yellow mosaic virus (ZYMV, Potyvirus) in cucurbits. Arch Virol 155:397-401

Díaz-Pendón JA, Ding SW (2008) Direct and indirect roles of viral suppressors of RNA silencing in pathogenesis. Annu Rev Phytopathol 46:303-326

Dietrich C, Maiss E (2003) Fluorescent labelling reveals spatial separation of potyvirus populations in mixed infected Nicotiana benthamiana plants. J Gen Virol 84:2871-2876

Ding S-W, Voinnet O (2007) Antiviral immunity directed by small RNAs. Cell 130:413-426

Ding S-W, Li W-X, Symons RH (1995) A novel naturally occurring hybrid gene encoded by a plant RNA virus facilitates long distance virus movement. EMBO J 14:5762-5772

Ding XS, Liu J, Cheng N-H, Folimonov A, Hou Y-M, Bao Y, Katagi C, Carter SA, Nelson RS (2004) The Tobacco mosaic virus 
126-kDa protein associated with virus replication and movement suppresses RNA silencing. Mol Plant Microbe Interact 17:583-592

Fuchs M, Gonsalves D (2008) Safety of virus-resistant transgenic plants two decades after their introduction: lessons from realistic field risk assessment studies. Annu Rev Phytopathol 45:173-202

Gal-On A (2000) A point mutation in the FRNK motif of the potyvirus helper component-protease gene alters symptom expression in cucurbits and elicits protection against the severe homologous virus. Phytopathology 90:467-473

Gal-On A, Shiboleth YM (2006) Cross-protection. In: Loebenstein G, Carr JP (eds) Natural resistance mechanisms of plants to viruses. Springer, Berlin, pp 261-288

Goto T, Nemoto M (1971) Studies on control of plant virus diseases by interference of attenuated virus-selection of TMV attenuated strain and influence on various plants inoculated with the attenuated strain (in Japanese). Res Bull Hokkaido Natl Agric Exp Stn 99:67-76

Goto T, Iizuka N, Komochi S (1984) Selection and utilization of an attenuated isolate of pepper strain of tobacco mosaic virus (in Japanese with English summary). Ann Phytopathol Soc Jpn 50:221-228

Goto K, Kobori T, Kosaka Y, Natsuaki T, Masuta C (2007) Characterization of silencing suppressor $2 \mathrm{~b}$ of cucumber mosaic virus based on examination of its small RNA-binding abilities. Plant Cell Physiol 48:1050-1060

Hagiwara K, Ichiki TU, Ogawa Y, Omura T, Tsuda S (2002) A single amino acid substitution in 126-kDa protein of Pepper mild mottle virus associates with symptom attenuation in pepper: the complete nucleotide sequence of an attenuated strain, C-1421. Arch Virol 147:833-840

Hagiwara-Komoda Y, Hirai K, Mochizuki A, Nishiguchi M, Meshi T, Ishikawa M (2008) Overexpression of a host factor TOM1 inhibits tomato mosaic virus propagation and suppression of RNA silencing. Virology 376:132-139

Holmes FO (1934) A masked strain of tobacco-mosaic virus. Phytopathology 24:845-873

Hughes Jd'A, Ollennu LAA (1994) Mild strain protection of cocoa in Ghana against cocoa swollen shoot virus-a review. Plant Pathol 43:442-457

Hull R (ed) (2002) Matthews' plant virology, 4th edn. San Diego, Academic Press

Ichiki TU, Nagaoka EN, Hagiwara K, Uchikawa K, Tsuda S, Omura $\mathrm{T}$ (2005) Integration of mutations responsible for the attenuated phenotype of Pepper mild mottle virus strains results in a symptomless cross-protecting strain. Arch Virol 150:2009-2020

Ieki H, Yamaguchi A, Kano T, Koizumi M, Iwanami T (1997) Control of stem pitting disease caused by citrus tristeza virus using protective mild strains in navel orange. Ann Phytopathol Soc Jpn 63:170-175

Kasschau KD, Carrington JC (1998) A counterdefensive strategy of plant viruses: suppression of posttranscriptional gene silencing. Cell 95:461-470

Kobori T, Ryang B-S, Natsuaki T, Kosaka Y (2005) A new technique to select mild strains of Cucumber mosaic virus. Plant Dis 89:879-882

Koonin EV (1991) The phylogeny of RNA-dependent RNA polymerases of positive-strand RNA viruses. J Gen Virol 72:2197-2206

Kosaka Y, Fukunishi T (1993) Attenuated isolates of soybean mosaic virus derived at a low temperature. Plant Dis 77:882-886

Kosaka Y, Fukunishi T (1997) Multiple inoculation with three attenuated viruses for the control of cucumber virus disease. Plant Dis 81:733-738

Kosaka Y, Ryang B-S, Kobori T, Shiomi H, Yasuhara H, Kataoka M (2006) Effectiveness of an attenuated Zucchini yellow mosaic virus isolate for cross-protecting cucumber. Plant Dis 90:67-72
Kubota K, Tsuda S, Tamai A, Meshi T (2003) Tomato mosaic virus replication protein suppresses virus-targeted posttranscriptional gene silencing. J Virol 77:11016-11026

Kurihara Y, Inaba N, Kutsuna N, Takeda A, Tagami Y, Watanabe Y (2007) Binding of tobamovirus replication protein with small RNA duplexes. J Gen Virol 88:2347-2352

Lewandowski DJ, Dawson WO (1993) A single amino acid change in tobacco mosaic virus replicase prevents symptom production. Mol Plant Microbe Interact 6:157-160

Lewsey M, Surette M, Robertson FC, Ziebell H, Choi SH, Ryu KH, Canto T, Palukaitis P, Payne T, Walsh JA, Carr JP (2009) The role of the Cucumber mosaic virus $2 \mathrm{~b}$ protein in viral movement and symptom induction. Mol Plant Microbe Interact 22:642-654

Lin S-S, Henriques R, Wu H-W, Niu Q-W, Yeh S-D, Chua N-H (2007a) Strategies and mechanisms of plant virus resistance. Plant Biotechnol Rep 1:125-134

Lin S-S, Wu H-W, Jan F-J, Hou RF, Yeh S-D (2007b) Modifications of the helper component-protease of Zucchini yellow mosaic virus for generation of attenuated mutants for cross protection against severe infection. Phytopathology 97:287-296

Loesch-Fries LS, Merlo D, Zinnen T, Burhop L, Hill K, Krahn K, Jarvis N, Nelson S, Halk E (1987) Expression of alfalfa mosaic virus RNA 4 in transgenic plants confers virus resistance. EMBO J 6:1845-1851

Maia IG, Haenni A-L, Bernardi F (1996) Potyviral HC-Pro: a multifunctional protein. J Gen Virol 77:1335-1341

McKinney HH (1929) Mosaic diseases in the Canary Islands, West Africa and Gibraltar. J Agric Res 39:557-578

Motoyoshi F, Nishiguchi M (1988) Control of virus diseases by attenuated virus strains: comparison between attenuated strains of cucumber green mottle mosaic virus and tobacco mosaic virus. Gamma Field Symp Inst Radiat Breed Natl Inst Agrobiol Resour 27:91-109

Nagai Y (1987) Production of C-1421, an attenuated mutant of pepper strain of tobacco mosaic virus. Ann Phytopathol Soc Jpn $53: 168-174$

Nakazono-Nagaoka E, Takahashi T, Shimuzu T, Kosaka Y, Natsuaki T, Omura T, Sasaya T (2009) Cross-protection against Bean yellow mosaic virus (BYMV) and Clover yellow vein virus by attenuated BYMV isolate M11. Phytopathology 99:251-257

Nishiguchi M, Kikuchi S, Kiho Y, Ohno T, Meshi T, Okada Y (1985) Molecular basis of plant viral virulence: the complete nucleotide sequence of an attenuated strain of tobacco mosaic virus. Nucleic Acids Res 13:5585-5590

Oshima N (1981) Control of tomato mosaic disease by attenuated virus. Jpn Agric Res Q 14:222-228

Plisson C, Drucker M, Blanc S, German-Retana S, Le Gall O, Thomas D, Bron P (2003) Structural characterization of HC-Pro, a plant virus multifunctional protein. J Biol Chem 278:23753-23761

Prins M, Laimer M, Noris E, Schubert J, Wassenegger M, Tepfer M (2008) Strategies for antiviral resistance in transgenic plants. Mol Plant Pathol 9:73-83

Qi X, Bao FS, Xie Z (2009) Small RNA deep sequencing reveals role for Arabidopsis thaliana RNA-dependent RNA polymerases in viral siRNA biogenesis. PLoS ONE 4:e4971. doi:10.1371/ journal.pone.0004971

Rast ATB (1975) Variability of tobacco mosaic virus in relation to control of tomato mosaic in glasshouse tomato crops by resistance breeding and cross protection. Agric Res Rep 834:1-76

Ratcliff FG, MacFarlane SA, Baulcombe DC (1999) Gene silencing without DNA: RNA-mediated cross-protection between viruses. Plant Cell 11:1207-1215

Salaman RN (1933) Protective inoculation against a plant virus. Nature 131:468

Sasaki A (1974) Studies on Hassaku dwarf. Spec Bull Fruit Tree Exp Stn Hiroshima Pref 2:1-106 
Sayama H (1996) Viral resistant tomato seedling production using attenuated cucumber mosaic virus (in Japanese). Plant Protect 50:20-25

Sayama H, Sato T, Kominato M, Natsuaki T, Kaper JM (1993) Field testing of a satellite-containing attenuated strain of cucumber mosaic virus for tomato protection in Japan. Phytopathology $83: 405-410$

Sayama H, Kominato M, Ubukata M, Sato T (2001) Three-year risk assessment of the practical application of cross-protection in processing tomato fields using an attenuated cucumber mosaic virus (CMV) strain containing an ameliorative satellite RNA. Acta Hortic 542:47-53

Schneider WL, Roossinck MJ (2001) Genetic diversity in RNA virus quasispecies is controlled by host-virus interactions. J Virol 75:6566-6571

Sherwood JL, Fulton RW (1982) The specific involvement of coat protein in tobacco mosaic virus cross protection. Virology 119:150-158

Shi B-J, Palukaitis P, Symons RH (2002) Differential virulence by strains of Cucumber mosaic virus is mediated by the $2 b$ gene. Mol Plant Microbe Interact 15:947-955

Shiboleth YM, Haronsky E, Leibman D, Arazi T, Wassenegger M, Whitham SA, Gaba V, Gal-On A (2007) The conserved FRNK box in HC-Pro, a plant viral suppressor of gene silencing, is required for small RNA binding and mediates symptom development. J Virol 81:13135-13148

Shintaku MH, Carter SA, Bao Y, Nelson RS (1996) Mapping nucleotides in the $126-\mathrm{kDa}$ protein gene that control the differential symptoms induced by two strains of tobacco mosaic virus. Virology 221:218-225

Soards AJ, Murphy AM, Palukaitis P, Carr JP (2002) Virulence and differential local and systemic spread of Cucumber mosaic virus in tobacco are affected by the CMV $2 \mathrm{~b}$ protein. Mol Plant Microbe Interact 15:647-653

Takahashi T, Sugawara T, Yamatsuta T, Isogai M, Natsuaki T, Yoshikawa N (2007) Analysis of the spatial distribution of identical and two distinct virus populations differently labeled with cyan and yellow fluorescent proteins in coinfected plants. Phytopathology 97:1200-1206

Tan S-H, Nishiguchi M, Sakamoto W, Ogura Y, Murata M, Ugaki M, Tomiyama M, Motoyoshi F (1997) Molecular analysis of the genome of an attenuated strain of cucumber green mottle mosaic virus. Ann Phytopathol Soc Jpn 63:470-474
Tien P, Wu G (1991) Satellite RNA for the biocontrol of plant disease. Adv Virus Res 39:321-339

Torres-Barceló C, Martín S, Daròs J-A, Elena SF (2008) From hypoto hypersuppression: effect of amino acid substitutions on the RNA-silencing suppressor activity of the Tobacco etch potyvirus HC-Pro. Genetics 180:1039-1049

Tsuda S, Kubota K, Kanda A, Ohki T, Meshi T (2007) Pathogenicity of Pepper mild mottle virus is controlled by the RNA silencing suppression activity of its replication protein but not the viral accumulation. Phytopathology 97:412-420

Vogler H, Akbergenov R, Shivaprasad PV, Dang V, Fasler M, Kwon M-O, Zhanybekova S, Hohn T, Heinlein M (2007) Modification of small RNAs associated with suppression of RNA silencing by tobamovirus replicase protein. J Virol 81:10379-10388

Yamanaka T, Ohta T, Takahashi M, Meshi T, Schmidt R, Dean C, Naito S, Ishikawa M (2000) TOM1, an Arabidopsis gene required for efficient multiplication of a tobamovirus, encodes a putative transmembrane protein. Proc Natl Acad Sci USA 97:10107-10112

Yambao MLM, Yagihashi H, Sekiguchi H, Sekiguchi T, Sasaki T, Sato M, Atsumi G, Tacahashi Y, Nakahara KS, Uyeda I (2008) Point mutations in helper component protease of Clover yellow vein virus are associated with the attenuation of RNA-silencing suppression activity and symptom expression in broad bean. Arch Virol 153:105-115

Yang G, Qiu B-S, Liu X-G, Li Y, Wang X-F (2002) Nonsense mutations of replicase and movement protein genes contribute to the attenuation of an avirulent tomato mosaic virus. Virus Res $87: 119-128$

Yeh S-D, Gonsalves D (1984) Evaluation of induced mutants of papaya ringspot virus for control by cross protection. Phytopathology 74:1086-1091

Yeh S-D, Gonsalves D, Wang H-L, Namba R, Chiu R-J (1988) Control of papaya ringspot virus by cross protection. Plant Dis 72:375-380

Zhang X, Yuan Y-R, Pei Y, Lin S-S, Tuschl T, Patel DJ, Chua N-H (2006) Cucumber mosaic virus-encoded $2 \mathrm{~b}$ suppressor inhibits Arabidopsis Argonaute1 cleavage activity to counter plant defense. Genes Dev 20:3255-3268

Ziebell H, Carr JP (2009) Effects of dicer-like endoribonucleases 2 and 4 on infection of Arabidopsis thaliana by cucumber mosaic virus and a mutant virus lacking the $2 \mathrm{~b}$ counter-defence protein gene. J Gen Virol 90:2288-2292 